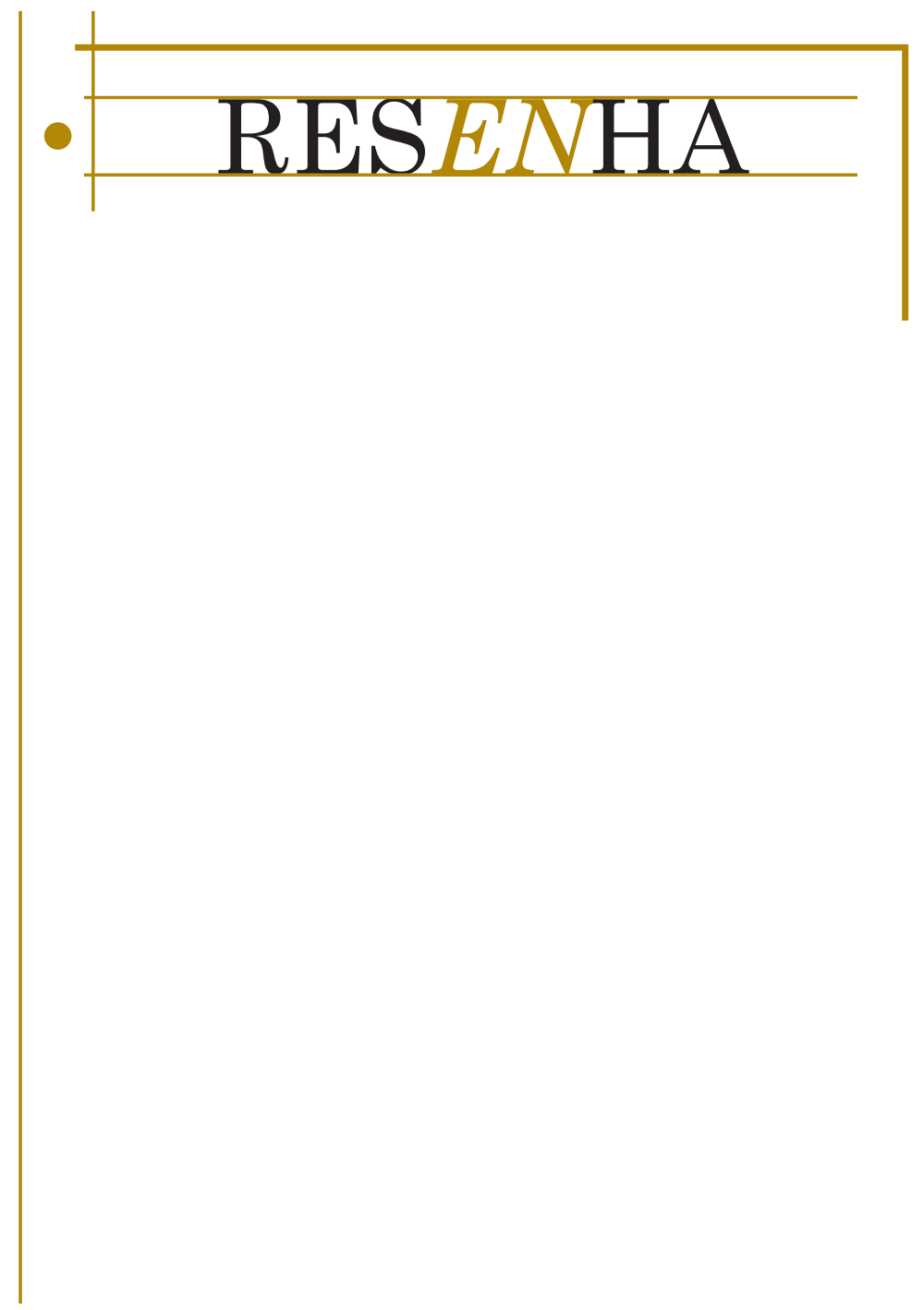




\section{DOENÇA, LITERATURA \\ E METÁFORA}

Daniela Schwarcke do Canto* Anselmo Peres Alós**

O ano era 1981. Quarenta e um jovens deram entrada em hospitais dos Estados Unidos apresentando sarcoma de Kaposi, um tipo raro de câncer que até então somente acometia pessoas idosas. Diferente do que acontecia nos pacientes idosos, nos quais o raro câncer de pele demorava anos para se agravar, nesses jovens pacientes o desfecho era rápido e mortal. Ao estudarem o perfil dos pacientes, os médicos notaram que eram todos homens homossexuais. Enquanto isso, os novos casos não paravam de surgir e a doença logo ficou conhecida como o "câncer gay", batizada de GRID, sigla em inglês para "imunodeficiência relacionada aos gays" (Gay-Related Immune Deficiency). Esse termo foi em seguida substituido por AIDS (Acquired Immune Deficiency Syndrome).

Não tardou para que a AIDS se mostrasse uma doença "não discriminatória", acometendo heterossexuais, mulheres e até crianças que haviam recebido transfusões de sangue e que agora se tornavam futuros transmissores em potencial. A falta de conhecimento dessa implacável doença, e a consequente falta de informações a respeito de formas de contágio e de prevenção, fez com que muitas pessoas fossem contaminadas no início dos anos 1980. Isso fez surgir uma espécie de pânico, que acarretou um cuidado muitas vezes excessivo, transformado, em última instância, em preconceito. Havia um medo generalizado de tocar nas pessoas infectadas e até mesmo de com elas dividir o ambiente de convivência.

Depois de muitas mortes e de muitas pesquisas, sabemos que a AIDS é causada pelo retrovirus HIV, que agride sem piedade o sistema imunológico da pessoa infectada. Existe hoje um coquetel de remédios capazes de atacar e enfraquecer o HIV, tudo isso às custas de muitos efeitos colaterais e sofrimento do paciente. O remédio chega a reduzir em 99\% a carga viral no organismo, mas é

\footnotetext{
Universidade Federal de Santa Maria (UFSM), Santa Maria, RS, Brasil. E-mail: danidocanto@hotmail.com

** Universidade Federal de Santa Maria (UFSM), Santa Maria, RS, Brasil. E-mail: anselmoperesalos@gmail.com
} 
ainda incapaz de eliminar o vírus por inteiro, levando a pessoa a um uso continuado vitalício do conjunto de medicamentos, pois se o uso do antirretroviral for interrompido, o vírus pode "acordar" e se multiplicar novamente, atacando o organismo. Mais de 30 anos após a descoberta dessa temida doença, os médicos já a tratam não mais como um atestado de morte iminente, mas como uma doença crônica que deve ser tratada e monitorada pelo resto da vida.

Se é verdade que a homossexualidade não raro é associada à morte, à culpa, à doença e ao vício ao longo da história da arte da literatura ocidental dos séculos XIX e XX, também é verdade que poucos criticos recordam que, antes da AIDS, a doença do anátema e da culpa foi o câncer, e que ele, em nenhum momento, foi associado a práticas sexuais ou sexualidades periféricas e não hegemônicas, embora não raro o câncer fosse associado a certos tipos de personalidade, tais como a depressiva, a melancólica ou a nervosa. Susan Sontag (1984, p. 16), autora de A doença como metáfora (um dos mais instigantes ensaios sobre as metáforas associadas ao câncer), salienta que:

De acordo com a mitologia do câncer, geralmente é uma firme repressão de sentimentos que causa a doença. Sob a forma mais antiga e mais otimista dessa fantasia, os sentimentos reprimidos eram de ordem sexual. Agora, fazendo um notável desvio, a repressão de sentimentos violentos é visto agora como causa do câncer.

Em Salón de belleza, quarta novela do escritor mexicano Mario Bellatin (publicada pela primeira vez em 1994), uma peste não nominada (mas que, em função de muitos indícios textuais, presume-se ser a AIDS) é narrada como um algoz mortal, sem cura, que inevitavelmente leva a sua vítima a uma morte cruel e dolorosa. O narrador sem nome conta-nos a sua história, desde os tempos em que saiu da casa da mãe, aos 16 anos, até os seus dias finais, já doente, em que rememora o passado e se preocupa com o que será feito de seu estabelecimento (um salão de beleza, localizado em algum centro urbano da América Latina, também não nomeado ao longo da narrativa) após a sua morte.

Ao longo da novela, o narrador, um(a) cabeleireiro(a) travesti, conta-nos a sua vida. Fala do trabalho em uma boate, onde conseguiu juntar dinheiro para abrir seu próprio salão. Um lindo e luxuoso salão, decorado com requinte e ornado por belos aquários de peixes. Fala de suas andanças pela noite atrás de homens que lhe dessem dinheiro e prazer, e de suas tardes em uma sauna da cidade. Fala com saudades desse tempo, um tempo que não volta mais. Seu corpo debilitado pela peste faz com que essas aventuras sejam agora apenas parte de sua memória.

O salão suntuoso, pensado para atender às clientes mais exigentes, agora abriga um Morredouro, onde homens homossexuais acometidos pelo "mal" e rejeitados pela família e pelos hospitais, já na fase terminal dessa peste, vão para esperar a morte chegar. Os peixes continuam lá, nos grandes aquários que outrora ornavam o salão, hoje um Morredouro. Já não são mais lindos e coloridos, a água é turva, mas mesmo assim, para o narrador, os aquários ainda são como um sopro de vida naquele lugar impregnado de morte.

O narrador não sabe precisar quantos enfermos já passaram por ali, quantos morreram ali. Mas sabe que, se batem à sua porta, é porque a peste já decretou a sua sentença de morte. Não aceita mulheres nem crianças, também não aceita homens que estejam nos primeiros estágios da doença. Remédios, rezas e 
apoio moral também são proibidos no Morredouro. O Morredouro tem suas regras que devem ser cumpridas. Assim, o narrador se mantém frio e capaz de lidar com a morte cotidiana de seus "hóspedes" enfermos. As tarefas do dia são cumpridas de maneira quase robótica, em uma rígida rotina. Podemos notar que há uma espécie de blindagem por parte de narrador. Ele não se envolve com os "hóspedes". São todos doentes iguais, sem rosto, sem passado e, principalmente, sem futuro. Sujeitos cuja identidade e história pregressa foram apagadas, em função da doença que os acomete. Ele nos conta que já se envolveu, uma vez, com um lindo rapaz que passou pelo Morredouro. Esse mereceu atenção especial e, na ocasião de sua morte, ganhou velório e enterro dignos. Mas ele não se envolve mais, os que morrem agora vão para uma vala comum. Os hóspedes não passam de corpos esperando a hora de encerrar sua vida terrena.

Se no passado o salão trazia mulheres velhas, com a pele gasta, à vida novamente, agora ocorre o oposto. As pessoas lá estão somente esperando a morte. Os mais afortunados morrem dentro de 15 dias. Alguns teimam em viver mais, mas a doença os leva igualmente. O narrador justifica a proibição de remédios no Morredouro dizendo que eles só prolongarão a dor e o sofrimento. Não há cura para o mal. Ele não deixa os hóspedes criarem expectativas de sobrevivência: "Quando acreditam que se recuperarão, tenho de lhes fazer entender que a doença é igual para todos" (BELLATIN, 2013, p. 30, tradução nossa) ${ }^{1}$. Para ele, não há maior bênção que a morte rápida. Os peixes dentro do aquário sujo são o maior elo do Morredouro com a vida: eles continuam lá, parcos sobreviventes, também à espera de uma morte que não tarda a chegar.

Já no final de sua vida, vendo que a doença também vai levá-lo em breve, assim como leva a todos que passam pelo Morredouro, o narrador se vê, pela primeira vez, preocupado com o futuro. Quem cuidará dele quando a doença lhe tirar totalmente as forças e a independência? Qual será o destino do salão assim que ele se for? Ele pensa em queimar o Morredouro com todos dentro, ou alagá-lo até que seja transformado em um aquário gigante... mas sabe que essas ideias são absurdas, totalmente carentes do glamour que ele quis impor ao salão. Vai esperar que todos os hóspedes morram para transformar o Morredouro novamente em um salão. Comprará tudo novo, afinal, dinheiro não é problema para ele, com todas as doações que recebe e uma ou outra herança deixada pelos mortos. Os aquários também voltarão a ter o esplendor do passado. Livrar-se-á dos peixes feios e sem graça, assim como as famílias que se livraram de seus moribundos, abandonando-os à própria sorte. Terá um salão lindo só para ele, e não abrirá as portas para ninguém. Morrerá, mas morrerá no luxo que sua mente foi capaz de inventar para si mesmo.

No fundo, ele sabe que essas são todas ideias soltas. O Morredouro vai permanecer como está. Quando ele morrer, provavelmente as Irmãs de Caridade tomarão conta, vão mudar as regras do Morredouro, e seguramente aceitarão mulheres. Ele será esquecido, assim como seu trabalho e seu tempo desperdiçado. O aquário de água turva e esverdeada, no entanto, permanecerá lá, pois parece ser a imagem mais adequada para ser a última visão de qualquer moribundo, figurando como metáfora agonizante da impotência humana perante a morte.

1 "Cuando creen que se van a recuperar, tengo que hacerles entender que la enfermedad es igual para todos". 
RESENHA

\section{REFERENCIAS}

SONTAG, S. A doença como metáfora. Tradução Márcio Ramalho. Rio de Janeiro: Graal, 1984. 